reflexion och konfrontation. Att denna reflexion är speciellt livlig i Danmark noterar gärna en svensk och förstår att det framförallt är giganterna Grundtvig och Kierkegaard som ger stoff til ständigt nya analyser och »opgør«.

Vad Grundtvig gett oss som ofrånkomligt arv att reflektera över, och praktisera, om vi så vill, är hur människans villkor ska kunna gestaltas som en verksamhet »for Mennesket) i Guds Billede« - som är en av Grundtvigs skoldefinitioner. Eller, lite annorlunda uttryckt: att verka för ett »Gudsbelätet värdigt människoliv«, som det hette i den lingske gymnastikrörelsen, ett av de få sammanhang där Grundtvig gjort sig gällande i Sverige. Och där dessutom en återexport till Danmark skedde!

Kanske är det då också så att vi oavlåtligen måste uppfinna »Gudbilledligheden « för varje särskild tid! Med allt risktagande det kan föra med sig, behöver det inte bli en förvanskning, utan snarare en inskrivning i livsförståelsen både av allmänmänsklig, existentiell erfarenhet och en möjlig erfarenhet av det specifika och exklusiva kristenlivet.

Luther eller Grundtvig - vi får tacka dem båda för att de har satt igång oss att bli trostänkare på ett sådant sätt, att det berör oss, så att vi aldrig kan sluta. Det tacket gäller också alla som visar sig i boken, så ock författaren!

\title{
Grundtvigs historiefilosofi til kritisk vurdering
}

\author{
Af Sigurd Aa. Arnes
}

Ole Vind: Grundtvigs historiefilosofi, Gyldendal, Kфbenhavn 1999, 645 s.

Innenfor Grundtvig-forskningen har det i de senere år vært en tydelig tendens til å stille det modne forfatterskapet $\mathrm{i}$ sentrum - $\mathrm{i}$ motsetning til den tidligere forsknings konsentrasjon om ungdomsverkene. Ole Vinds ferske doktoravhandling, Grundtvigs historiefilosofi, er i så måte tidstypisk. Til overmål handler den også om to av det senere forfatterskaps hovedverker Haandbog $i$ Verdens-Historien (1833 - 56) og Nordens Mythologi (1832) - med sideblikk til Christenhedens Syvstjerne (1860) og Kirke-Speil (1871). Mer og mer fremtrer 1830-årene for oss i dag som »høydedraget« i Grundtvigs forfatterskap. Det var jo også $d a$ hans salmediktning brøt frem med uhørt kraft.

Den ambisiøse tittelen på Vinds avhandling er altså Grundtvigs historiefilosofi, men den handler ikke bare om verker som vi i dag ville oppfatte som historieskrivning. Forfatteren beskjeftiger seg også med en håndbok $\mathrm{i}$ nordisk mytologi (Nordens Mythologi), et »kirkeligt Sagakvad« (Christenhedens Syvstjerne) og en kirkehistorie (Kirke-Speil) - tekster som vi jo ikke umiddelbart forbinder med en historiefilosofi.

Vind taler da også flere steder i sin avhandling om Grundtvigs »dobbelte bogholderi« av verdenshistorie og kirkehistorie, men egentlig har vi vel å gjøre med en slags tredelt »bogholderi« i og med at den førkristne nordiske myteverden også trekkes inn i fremstillingen. Først og fremst forteller dette sitt om hvor forskjellig Grundtvigs historiebegrep er fra vårt. 
Avhandlingen er komponert i fire hoveddeler. Kjernen i verket er tydelig del II og III med de brede gjennomgåelsene av Nordens Mythologi og Haandbog $i$ Verdens-Historien, henholdsvis under overskriftene »Universalhistorisk Vidskab« og »Universalhistorisk Udvikling «. Denne sentrale delen av avhandlingen er så omsluttet av en innledende del som særlig handler om Grundtvigs tyske lærmestre i historiefilosofien (Fichte, Schelling, Lessing, Schlegel og fremfor alt Herder) og en avsluttende del som først og fremst dreier seg om den grundtvigske historiefilosofis virkningshistorie fra Grundtvigs samtid til i dag.

Ikke minst for en utenlandsk leser er denne delen av avhandlingen interessant fordi den fører rett inn i den danske åndshistoriske tradisjon som Vinds avhandling springer ut av og knytter an til. Jeg nevner særlig de levende og personlig engasjerte karakteristikkene av grundtvigske tradisjonsbærere som Holger Begtrup (s.505f.) og C.P.O. Christiansen (s. 515f.). Som hos Begtrup synes også hos Vind den vitenskapelige utforskning av Grundtvigs ideverden å ha foregått $\mathrm{i}$ forlengelsen av den daglige lærervirksomhet - til overmål ved Begtrups egen skole, Grundtvigs Højskole Fredriksborg.

Vind bekjenner da også til slutt i sin avhandling at »i denne undersøgelse har både forskningshistorien og den grundtvigske historiefilosofis senere skæbne i højskolen fra første begyndelse udgjort en stadig nærværende baggrund for den dialog med Grundtvigs eget værk som hermed afsluttes« (548). Dette skinner så tydelig gjennom at forfatteren nesten ikke hadde behøvd å fortelle oss det!

Gjennom avhandlingen merker vi også hele tiden hvordan forfatteren selv er involvert i de tanker han tar livtak med. Han er selv så tydelig part i saken - uten tvil en god utgangsposisjon for en idehistorisk analyse. Med en henvisning til Gadamer minner Vind i et understatement om at »det ikke nødvendigvis gør tolkningen af Grundtvig mindre videnskabelig eller gyldig, at man hos Grundtvig finder sandheder man selv tør stå inde for $\ll(33$, jf. 548).

Vinds kontakt med en grundtvigiansk pedagogisk tradisjon merker man også i forfatterens jevne og allmennforståelige prosa uten det overforbruk av »Kunst-Ord « som så ofte er plagsom i våre akademiske miljøer. Vind skriver ikke kryptisk og innforstått for eksperter, men i beste grundtvigianske tradisjon jevnt og naturlig for »den alvorligt interesserede« (19). Personlig har jeg hatt særlig glede av hans brede episke gjennomgåelsen av Haandbog $i$ Verdens-Historien i del II, der han gjenforteller, sammenfatter og perspektiverer på en mønstergyldig pedagogisk måte.

Metodisk karakteriserer Vind selv sitt verk som »et traditionelt idehistorisk arbejde« (15). Hans formål er »at belyse og karakterisere Grundtvigs historiefilosofi i dens sammenhæng med den historiefilosofiske tradition« (14).

Det må likevel understrekes at Vind ikke på tradisjonell måte primært er opptatt av litterær påvirkning og forfatterrespons. Hans grunnspørsmål er ikke »hvor og hos hvem Grundtvig først mødte en tanke eller ide, men snarere ideens vægt i Grundtvigs eget syn betragtet i forhold til og sammenhæng med ideens betydning i den europæiske tradition« (153). Det Vind er ute etter, er ikke primært »Grundtvigs udnyttelse af kilderne«, men det »perspektiverende syn hvormed han går til kilderne « (274). Vi har altså i prinsippet å gjøre med en tidstypisk metodisk forskyvning fra en genetisk til systematisk lesemåte.

Det forhindrer imidlertid ikke at Vind i praksis opererer på samme måte som eldre forskere (Scharling, Michelsen): Han parallelleser Grundtvigs tekster med Herders og de andre tyske historiefilosofers skrifter. Hvor Vind så finner klare overensstemmelser, noterer han et påvirkningsforhold - noe som altså for ham selv ikke fremtrer som 
hovedsaken - men som et nødvendig ledd i hans karakteristikk av vedkommende Grundtvig-tekst.

Et påfallende trekk ved avhandlingen er at hvor tidligere grundtvigforskere konsekvent talte om en påvirkning fra tysk romantikk, taler Vind i forbindelse med det samme skriftkorpus like konsekvent om en påvirkning fra tysk opplysningsfilosofi. Går man ut fra en tradisjonell definisjon av »opplysningsfilosofi« som for eksempel den man finner i Norsk riksmålsordbok, bd. II, 1, Oslo 1947, sp. 500) - »en fil. rasjonalistisk retning i det $18 \mathrm{de}$ århundres annen halvdel som hevdet den frie tankes rett overfor all historisk sammenheng « - så virker Vinds terminologi umiddelbart forvirrende, ikke minst fordi den sentrale »opplysningsfilosof « $i$ hans fremstilling er Herder.

Vinds spesielle terminologi fører med seg at han gjør front mot praktisk talt hele den tidligere grundtvigforskning. Mens denne altså var opptatt av de romantiske motiver hos Grundtvigs tyske forbilder, fremhever Vind konsekvent »arven fra oplysningstiden « hos de samme læremestre: »Der er i dag «, hevder han programatisk »god grund til en ny besindelse på arven fra oplysningstiden« (552). Hele Vinds avhandling kan karakteriseres som et forsøk på en slik besinnelse.

På denne bakgrunn er det påfallende at Vind har vært så lite opptatt av å klargjøre sin egen spesielle bruk av termen »oplysningsfilosofi «(som jeg vil gjette på har moderne forbilder). I et sentralt utsagn på s. 256 skjelner han en passant mellom det han kaller »den i snævrere forstand romantiske inspiration« fra tysk filosofi »med den høje vurdering af poesien og de poetiske syners glimt fra evighedsindsigt« og »arven fra oplysningstiden, med troen på oplysning, videnskabelighed og fremskridt og den historiefilosofiske drøm om den store universalhistorie som spejl for menneskets højeste drømme, opgaver og håb«.

Vind hevder så at »denne side af inspirationen fra den tyske filosofi fik større betydning for Grundtvig end den i snæver forstand romantiske« og at »hvis ikke den unge Grundtvigs romantisk-poetiske evighedsdrøm hurtigt var gået op i den historisk poetiske fremtidsdrøm, havde Grundtvig næppe fået så stor betydning i samfunds- og folkelivet i Danmark« (256).

På denne bakgrunn nedtoner Vind gjennom hele sin avhandling »den i snæver forstand romantiske inspiration « $\mathrm{i}$ forhold til den sterkt fremhevde »arv fra oplysningstiden «. Ja, han går så langt som å lansere Grundtvig som opplysningstenkeren »fremfor nogen i Danmark «(59). Grundtvigs historiefilosofi er ifølge Vind »en original udformning af den udviklingsoptimisme og fremskridtstro, som var en arv fra oplysningstidens tænkning « (431, jf. 253, 431 og mange flere steder).

Det som ifølge Vind skjer er at Grundtvig »i sin historiefilosofis fremtidshorisont « »direkte sammensmelter tidens dristige, revolutionære slagord med den første kristne menigheds forbilledlige tilstand « - noe som i Vinds optikk »hører til det mest originale og virkningsfulde« i Grundtvigs syn (434).

At Vind i sin fremhevelse av »arven fra oplysningstiden « har et poeng, er jeg ikke i tvil om. Men det går som det så ofte skjer når man oppdager noe nytt: Det nye fyller lett hele blikkfeltet, slik at de gamle innsikter ikke får komme til sin rett som en del av det nye totalbildet. Grundtvigs egne unnsigelser av opplysningstiden, rasjonalismen og alt dens vesen er et så gjennomgående tema gjennom hele hans forfatterskap at det etter min mening skal sterkere historiske argumenter enn de Vind fremlegger (148f. og 552) for så radikalt å tone ned den dypt internaliserte romantiske arv - ikke minst språkarv - hos Grundtvig.

For bare å nevne ett eksempel: Hadde den språkbehandling vi finner i Grundtvigs salmer og øvrige lyrikk overhodet vært mulig uten de romantiske mønstre han møtte i 
sine mest mottagelig ungdomsår? Det er riktig - som også Vind fremhever - at Herder her med sin språkfilosofi må ha vært en av Grundtvigs fremste læremester (jf. 65f., 137 og flere steder), men da gir det etter min mening gale assosiasjoner - som Vind gjør - så ensidig å tale om opplysningsfilosofen Herder. Her har vi å gjøre med førromantikeren.

Vinds egen fremstilling viser jo også at Herder representerer så mye mer enn opplysningstenkning i ordets tradisjonelle betydning. Han står også - som Vind et sted nevner - »som ophavsmand til historisme, kulturrelativisme og nationalisme «(554). Hele denne romantiske språkarv fra Herder burde etter min mening ha blitt tillagt større vekt i Vinds argumentasjon. Kanskje bruddet med grundtvigforskningens tradisjonelle sammenstilling av Grundtvig og romantikken da ikke hadde blitt så unødvendig skarpt som det har blitt i Vinds fremstilling?

Mens altså Vind etter min mening burde forholdt seg mer bevisst overfor overordnete idehistoriske hovedbegreper som »oplysningsfilosfi» og »romantik«, er han på en ganske annen måte bevisst $\mathrm{i}$ sin omgang med Grundtvigs egen termonologi. Her »mærker « han stadig »Ord « - for å bruke Grundtvigs egen betegnelse for denne typen virksomhet. Vind viser også sans for den særegne dynamikk i sin helts begrepsverden. Han taler om »Grundtvigs gennem årtier opbyggede teologiske, mytologiske og historiske tankerverden«, der »enkelte ord kan være ladet med særegne betydninger, ligesom han sjældent uddyber en gang nøjere begrundede indsigter« (20).

Hele kapitler i Vinds avhandling handler simpelthen om sentrale begreper i Grundtvigs terminologi som »Folk og Folkeaand «(111 - 123), »Det naturlige levnedsløb«(133 - 136), »Historisk Vidskab« (137 - 147), »Fremskridt og Forsyn« (253 - 260), »Gyldenåret « (413 - 420) og »Forklaringsmaalet« (s.413 - 426). Og underveis i den løpende fremstilling stanser han ofte opp for »mærke« Grundtvigs »Ord«.

Som tilfeldig valgte eksempler nevner jeg »de høinordiske Øine« (206 - 207), »Lyset « (207 og 259 - 260), »Kraft« (323) og »Aand «»Folkeaand « (293, 323, 378f.) og her er mange flere. Det ville ha $\emptyset \mathrm{kt}$ avhandlingens nytteverdi om Vind hadde gitt seg tid til også å ha utarbeidet et begrepsregister. Ja, med vår tids datateknikk er det jo ikke lenger urealistisk å drømme om et grundtvigsk begrepsleksikon à la det Kierkegaard forlengst har fått!

Skulle jeg etter denne altfor korte omtalen utforme en konklusjon, vil jeg si at Grundtvigs historiefilosofi både i seg selv er et betydelig verk og interessant som tidstypisk fenomen. Som all god humanistisk forskning er Vinds avhandling sprunget ut av en eksistensiell problemstilling: Hvordan skal vi i dag forholde oss til arven fra Grundtvig - i en tid da hverken hans kristne tro eller hans nasjonalitetsbevissthet lenger er selvfølgelige for alle? Hvordan gjenvinne et medmenneskelig samtalefellesskap i en tid preget av atomisering, en (for å tale med Grundtvig) »Uafhængighed af det Folk, den Slægt og den Gud « hver enkelt tidligere følte en grunnleggende tilhørighet til (557f.)?

Vind finner svaret $\mathrm{i}$ det han kaller Grundtvigs »åndshistoriske antropologi«, en »historisk oplysning «, som med Grundtvigs egne ord skal oppklare »den dybe Sammenhæng mellem Enkelt-Mandens, Folkets og hele Slægtens Liv« (562). Som Grundtvig i sin tid ville inkludere »Naturalister med Aand « i et dansk og nordisk samtalefellesskap, slik drømmer Vind i dag om et videre europeisk fellesskap, der også alle de skal integreres som hverken deler Grundtvigs kristentro eller hans følelse av å tilhøre et bestemt nasjonalt fellesskap.

Det dreier seg om et slags europeisk ideologisk »minste felles multiplum«, som Vind til og med vil ha utformet $i$ »en central europæisk grundfortælling om de sidste 250 års ideer og begivenheder « (552). I det radikalt reduksjonistiske Grundtvig-bildet dette synes å kreve, gjør Vind også kort prosess med »forbindelsen mellem det nationale og 
det kristne« som noe tidsbundet og derfor utskiftningsmodent i Grundtvigs syn (23). I dette situasjons- og tidsbestemte moderniseringsbehov finner vi vel den personlige bakgrunn for Vinds dyrkelse av »opplysningstenkeren« Grundtvig. 